\title{
Contributions
}

Malte Fabian Rauch

\section{Silence / Signification Degree Zero: Walter Benjamin's Anti-Aesthetic of the Body}

https://doi.org/10.1515/arcadia-2018-0021

\begin{abstract}
This essay examines Walter Benjamin's opposition against traditional aesthetics and his development of an alternative, a decidedly anti-aesthetic approach. More specifically, it focuses on how Benjamin launches a frontal attack on Idealist aesthetics in the theory of ancient tragedy expounded in the Trauerspiel book and how he develops his own alternative conception in critical delineation from it. Closely examining his engagement with Nietzsche, Hölderlin, Hegel, and Solger, the essay shows how Benjamin's entire theory is construed as a pointed response to a long and complex discourse on tragedy. Through a reconstruction of these debates, it becomes evident that the core of Benjamin's critique concerns the relation between universal and singular in Idealist aesthetics, spelled out in a theory of reconciliation that is directly tied to the themes of fate and sacrifice. Against this background, the essay then analyzes - drawing both on Benjamin's reception of Franz Rosenzweig as well as the work of Giorgio Agamben - Benjamin's notion of silence as a retreat from language and meaning, as an immersion into the body. Instead of offering an image of reconciliation, tragedy, for Benjamin, then appears as the site where bodily singularity and impotentiality fragments the totality of signification, where meaning is disrupted and reduced to degree zero.
\end{abstract}

Keywords: Walter Benjamin, anti-aesthetics, body, creaturely, silence, Idealist aesthetics, fate, sublime, theory of tragedy, tragic, impotentiality

"Unhappiness obtains only as long as the will of necessity is not yet decided and apparent. As soon as the hero himself achieves clarity, and his fate lies open before him, there is no more doubt for him, or at least there should not be. And precisely at the moment of greatest suffering he enters into the greatest liberation and dispassion.” F. W. J. Schelling, Philosophie der Kunst (trans. modified)

Corresponding author: Malte Fabian Rauch, Humboldt Universität zu Berlin, Institut für Philosophie, Unter den Linden 6, D-10099 Berlin, Deutschland, email: raucm763@newschool.edu 
"Happiness is, rather, what releases the fortunate man from the embroilment of the Fates and from the net of his own fate. Not for nothing does Hölderlin call the blissful gods 'fateless' [...]. It was not in law but in tragedy that the head of genius lifted itself for the first time from the mist of guilt, for in tragedy demonic fate is breached. Walter Benjamin, “Schicksal und Charakter” (trans. modified)

\section{Introduction}

In Walter Benjamin's entire work, the categories of traditional aesthetics do not fare well. From the notion of individual genius to the idea of timeless values and harmonious beauty, an entire conceptual apparatus is frontally attacked by means of a decidedly anti-aesthetic approach. ${ }^{1}$ The seven-headed "hydra of school aesthetics" (Benjamin, "Literaturgeschichte und Literaturwissenschaft" 286), ${ }^{2}$ whose enemy Benjamin declared himself to be, was the pitiful afterlife of the traditional categories of aesthetics, which in the German discourse of Benjamin's time was above all the institutionalized version of Idealist aesthetics. It is for this reason that Benjamin targets his critique - frequently in oblique ways explicitly against the basic categories of Idealist aesthetics. Already in his dissertation on Romanticism, Benjamin insists that when measured against the contemporary academic discourse, the "state [Stand] of the German philosophy of art from around 1800" - that is, the period of Idealist and early Romantic aesthetics - is still "legitimate" ("Der Begriff der Kunstkritik" 117). The philosophy of art from this period is legitimate, but not in the sense of an ideal that is to be recuperated. Hardly so. Legitimate it is but as a legacy that needs to be taken into account in developing an alternative approach in critical delineation from it. ${ }^{3}$

1 Throughout this essay, anti-aesthetic is used in a restrictive sense to denote a general opposition against the traditional formulation of aesthetics in the tradition of the $18^{\text {th }}$ century. The view thus attributed to Benjamin is in certain respects akin to, yet certainly not identical with, the debate about the term in the 1980s. Cf. Foster; as well as the recent roundtable discussion of this term in Elkins and Montgomery, a volume that considers the relation of Benjamin to this discourse (39-45).

2 In the 1930s, Benjamin would draw terminal consequences from the fate of traditional aesthetic categories, describing the intent of his own theses on art as follows: "They neutralize a number of traditional concepts - such as creativity and genius, eternal value and mystery - which, used in an uncontrolled way [...] allow factual material to be manipulated in the interests of fascism. In what follows, the concepts which are introduced into the theory of art differ from those now current in that they are completely useless for the purposes of fascism." (Benjamin, "Das Kunstwerk" 435; "The Work of Art" 101-102)

3 This holds true for both Romanticism and Idealism, even if Benjamin's stance towards Romanticism is, of course, much more sympathetic. 
This essay is dedicated to a little understood chapter of Benjamin's opposition to traditional aesthetics and the development of an alternative, anti-aesthetic approach. Thematically, it concerns the theory of ancient tragedy developed in the Trauerspiel book; materially, it concerns the contours of one of his most central concerns. Benjamin's engagement with ancient tragedy occurs on a few pages of the Trauerspiel book, in a densely woven textual fabric characterized by strategic positioning and attacks that are carried out under disguise, in footnotes and allusions. In a minutely composed composition, Benjamin settles his account with a long and complex discourse on tragedy, sharply marking his allies and enemies. Reading these subtexts will make it necessary to follow Benjamin's references through different theoretical contexts. What will ultimately emerge as the vanishing point of these detours is an attack on the understanding of the relation between universal and singular in Idealist aesthetics, spelled out in a theory of reconciliation that is directly tied to the themes of fate and sacrifice. To this, Benjamin opposes an anti-aesthetic notion of the sublime, centered around the notion of silence, singularity, and the body. His will not be a story about tragedy's consolation and edification. This much is sure. His will be a theory about tragedy's historical significance, about its political meaning. Such are the stakes in this confrontation.

First, however, a note on the emergence of the theory of ancient tragedy and its treatment in the literature is in place. On 19 February 1925, immediately after finishing the first draft of the Trauerspiel book, Benjamin tells Gershom Scholem in a letter about the work's final structure and mentions, as if in passing, that it would also contain a new "theory of tragedy" (Tragödientheorie). ${ }^{4}$ Although Benjamin did contemplate the possibility of developing his own theory of ancient tragedy during the earliest phase of his research, he remained skeptical as to whether he could integrate it into the book, given the radical divergence of his approach from the academic literature of the day. ${ }^{5}$ It cannot be determined precisely when the decision to integrate the theory into the book was finally taken, and it is indeed possible that it was a spontaneous one. But Benjamin's extensive correspondence on the theme with Florens Christian Rang, who provided the inspiration for several elements of Benjamin's theory, and the density of its final formulation can leave no doubt about its importance, both with regard to

4 Cf. Benjamin's letter “An Gershom Scholem. Frankfurt a.M. 19. 2. 1925” (14); “To Gershom Scholem. Frankfurt Main, February 19, 1925” (261).

5 See Benjamin's letter “An Florens Christian Rang. Berlin, 14. 2. 1924” (423). Benjamin's editors date the surviving schemas for the Trauerspiel book, some of which include a planned theory of ancient tragedy, to the earliest phase of Benjamin's research. Cf. Benjamin, Gesammelte Schriften (I: 914-920). 
Benjamin's project and the discussion of the philosophy of tragedy more generally.

In the argument of the Trauerspiel book, the theory of ancient tragedy is supposed to support one of Benjamin's central concerns, namely that there is a generic difference between ancient tragedy and the Baroque Trauerspiel, which contemporary Baroque scholars commonly judged to be merely a primitive imitation of the ancient form. ${ }^{6}$ As such, the theory is part of Benjamin's argument that the Baroque Trauerspiel has to be understood as being governed by its own generic principles, rather than being measured by the standards of Neoclassicism. However, as is clear from his references, Benjamin also intended his theory to be an intervention into various discourses on tragedy stretching from Idealism to the contemporary discussion. ${ }^{7}$ Several recent studies have been dedicated to detailed reconstructions of these debates. Particular attention has been devoted to the relation between Benjamin and those contemporary theorists who served as reference points for different parts of Benjamin's argument. ${ }^{8}$ While these studies have been highly instructive for a contextualized understanding of the Trauerspiel book, the exclusive focus on a reconstruction of the contemporary context tends to obliterate the fact that Benjamin clearly intended his theory to be not only a contribution to the contemporary debate, but also a critique of Idealist philosophies of the tragic. Peter Szondi's seminal Versuch über das Tragische was the first study to reconstruct the invention of philosophies of 'the tragic' as such - as opposed to theories of tragedy - around 1800. A flood of books and articles were to follow in Szondi's wake, and by now this paradigm belongs to the most wellresearched developments in Idealist philosophies of art. ${ }^{9}$ But Benjamin was evidently aware of this paradigm and its aftermath in German aesthetics when he wrote the Trauerspiel book, as evinced by the fact that he explicitly targets his critique against what he names the German "philosophy of tragedy" ("Philosophie der Tragödie," "Ursprung” 279).

Following Benjamin's framing, the interpretation developed here locates his theory within the context of German aesthetics around 1800, reading it as a

6 For a detailed account of these discussions in Baroque scholarship, cf. Newman (28-40).

7 For a good overview of the Weimar discourse on tragedy that gives particular attention to Benjamin, cf. Thaler. Helpful as an overview is furthermore Mack (part 2).

8 These are Florens Christian Rang, Georg Lukács, and Franz Rosenzweig. On Rang, cf. Asman (606-624); Jäger; Weber (163-168). On Lukács, cf. Thaler (55-56, 119-129, and ch. 11); Féher (125138). On Rosenzweig, cf. Mosès, "Walter Benjamin und Franz Rosenzweig” (esp. 624-629); Thaler (189-197).

9 Cf. Szondi, Versuch über das Tragische. From the by now considerable literature, cf. in particular Krell; Billings, Genealogy of the Tragic (esp. chs. 3-5); and the essays collected in Hühn and Schwab. 
response to the tradition of Idealist philosophies of tragedy. Although such a perspective was originally hinted at in Szondi's classical study, in the pages to follow it will also transpire that Szondi, the self-proclaimed Hegelian, was far too eager to assimilate Benjamin into a discourse he was, in fact, subverting. Even more striking than this, however, is that this entire research perspective has until now been almost completely neglected in the vast literature on the Trauerspiel book..$^{10}$ And the one study that follows Szondi's lead and situates Benjamin's theory of tragedy in the context of the tradition of Idealist aesthetics - Marc Sagnol's Tragique et Tristesse - neglects the relevant intertextual links almost completely in order to focus on a more conventional comparison between Tragik and Trauer in the respective texts (Sagnol, esp. chs. 4, 6, 7, and 10). ${ }^{11}$ Still more striking than this, however, is that the single text Benjamin cites explicitly as an example of the Idealist philosophies of tragedy he wishes to oppose is conspicuous in the scholarship only through its absence. This is K. W. F. Solger's "Über Sophokles und die alte Tragödie" (On Sophocles and Ancient Tragedy), a text that Solger originally wrote as a general philosophical introduction to tragedy in 1808 . Yet, in the following pages, this text, which has been surrounded by silence thus far, will prove decisive for understanding Benjamin's critique of Idealism.

Structured by thematic sections that unravel the different strands in Benjamin's dense textual fabric, this essay tracks Benjamin's self-positioning within the complex discourse of aesthetics. Setting out with a consideration of his relation to Friedrich Nietzsche, which frames and prepares everything to follow, it moves to an analysis of Benjamin's critique of Solger and the implications this has for his general opposition to the Idealist discourse, as exemplified by Solger, G. W. F. Hegel, and Friedrich Hölderlin. These excursus lead, in the final section, to an exposition of Benjamin's theory of tragedy as a frontal assault on Idealism and the development of anti-aesthetics of silence, of meaning disrupted and reduced to degree zero. Instead of a reconciliatory moral edifice, tragedy will emerge as the site where bodily singularity and impotentiality fragments the totality of signification.

10 Szondi, Versuch über das Tragische (200-204). Recent studies that do venture to explore the link between Benjamin and the $19^{\text {th }}$-century discourse on tragedy are mostly concerned with the relation between Benjamin and Nietzsche. Cf. Helfer; James McFarland; Honold.

11 Noteworthy is also Billings's recent work, which at least gestures towards a discussion of Benjamin's relation to the Idealist tradition. Cf. Billings, "Margins of Genre.” 


\section{Confronting Nietzsche}

The Trauerspiel book falls into two parts, the first of which deals with a historicophilosophical contextualization of the Baroque Trauerspiel, the second with an analysis of its linguistic means of expression, in particular the Baroque allegory. These parts correspond, roughly, to Benjamin's terminological distinction between the 'material content' and 'truth content' of an artwork (Benjamin, "Ursprung" 390). The first, contextualizing part of the book, programmatically entitled "Trauerspiel and Tragedy," is structured into three chapters. In the first chapter, Benjamin already goes to some lengths in developing arguments for the generic difference between ancient tragedy and Baroque Trauerspiel. Tragedy and Trauerspiel, Benjamin suggests, are literary forms that depend on certain historical preconditions, conditions that no analysis can abstract from without falling prey to interpretative delusions, be they formalistic, metaphysical, or psychologistic.

One of the arguments in support of this thesis - that the real content of ancient tragedy is myth, while the content of the Baroque Trauerspiel is a conception of history that lacks an eschatological dimension - clearly anticipates Benjamin's analysis of ancient tragedy (242-243). Yet it is only at the beginning of the second chapter that Benjamin interrupts the first chapter's line of argumentation and starts in earnest to develop his theory of ancient tragedy. This structural peculiarity - the only real interruption of the anti-narrative, montage-like technique Benjamin otherwise employs in the book - could be due to the fact that the final decision to integrate the theory was a spontaneous one, or that Benjamin refrained from undertaking the immense task of presenting ancient tragedy as an 'idea,' that is, according to the method expounded in the preface and realized in the remainder of the book for the Baroque Trauerspiel. ${ }^{12} \mathrm{Be}$ that as it may. Benjamin's core argument is then laid out in a comparatively short passage (279297), which moves between different levels of analysis and deals with a vertiginous number of authors, to be partly taken up again in the subsequent discussion that highlights the distinctness of the Baroque Trauerspiel (298, 300). It is an extremely dense passage, even by standard of the book, yet it is a passage with a

12 On this point, the reading proposed here fundamentally disagrees with Szondi (Versuch über das Tragische 201-202). Szondi takes Benjamin to be analyzing tragedy as an idea, but both the structure of Benjamin's argument and his phrasing that the theory concerns tragedy's "material content" speak strongly against this reading: Without a discussion of ancient tragedy's truth content, and hence its language, it cannot appear as an idea in the Benjaminean sense. For this phrasing, cf. Benjamin, “Ursprung” (279). 
finely composed dramaturgical structure. In what one might call the opening to his main argument, Benjamin situates himself through three argumentative steps which establish his position: first, against ahistorical accounts of 'the tragic'; second, against Nietzsche's theory; and, third and most importantly, against the Idealist philosophies of tragedy, as exemplified by Solger.

The first move in the argument sets out with a polemic against one of the standard works of philosophies of 'the tragic' in late $19^{\text {th }}$ - and early $20^{\text {th }}$-century academic aesthetics, Johannes Volkelt's Ästhetik des Tragischen (first published in 1897 and reprinted in numerous editions). The work is singled out by Benjamin as the culmination of the psychologistic line of $19^{\text {th }}$-century theories of 'the tragic,' that most reductive form of aesthetics. At this point, Benjamin's most urgent concern is to emphasize that the specificity of ancient tragedy cannot be understood apart from its historical context, and that the idea of the tragic as a timeless "universally human content" is therefore utterly untenable ("Ursprung" 280). For the consolations of such a naive humanism are ultimately bound to rely upon ahistorical premises and a reductive psychology, both of which equate the responses of various audiences in order to distill a concept of the tragic that is as empty and abstract as the notion of humanity to which it is said to correspond. But, Benjamin objects: "In truth there is nothing more problematic than the competence of 'modern humanity's' unguided feelings, in particular when it concerns the judgement of tragedy" (280).

In order to challenge any such conception, Benjamin uses Nietzsche's interpretation of the sources and meaning of ancient tragedy. Nietzsche, Benjamin asserts, was the first theoretician to gain insight into "tragedy's link to myth and the independence of the tragic [des Tragischen] from the ethos" (280), a phrase that already signals Nietzsche's crucial role in undermining the rampant moralization of tragedy in Idealist aesthetics. Benjamin is here not following the standard narrative of Nietzsche as the pessimistic, rough and raw reversal of those fantasies of Hellenistic harmony and original plentitude that emerged in the wake of Winckelmann and were endlessly variated in $18^{\text {th }}$ - and $19^{\text {th }}$-century German literature. Nietzsche's "emancipation" concerns, rather, what Deleuze describes - with Artaud - as his "having done with judgment" (126). It is the emancipation from an "infinite debt," a form of guilt to which Nietzsche saw human existence, in the Western tradition, as being always and already "subject” (126). Having done with it is the precondition for reading tragedy. Benjamin will name this infinite debt "fate," and he will describe it as an unfathomable debt that shows itself "in the view of life as condemned, as having essentially first been condemned and then become guilty (Benjamin, "Schicksal und Charakter" 174-175). Benjamin's will not be a story of tragedy's edifying qualities, nor one about tragedy's lofty moral lessons. It will be a theory about its historical significance, about its political truth. 
Yet, Benjamin's initial praise for Nietzsche is immediately qualified through the charge of "aestheticism," a failure that in Benjamin's view prevented Nietzsche from understanding "the concept of the hard, historical reality [Gegebenheit] of Greek tragedy” (“Ursprung” 282). Nietzsche reverses Idealist moralizations, and rightly so; but he will not be Benjamin's guide to tragedy's political stakes. The passage Benjamin singles out in order to reveal the failure of Nietzsche's aestheticism is crucial; he cites section 22 of Die Geburt der Tragödie, where Nietzsche describes tragic myth as "the transformation of Dionysiac wisdom into images [Verbildlichung] by means of Apolline artistic means [Kunstmittel]," a transformation that "leads the world of appearances to its limits where it negates itself and seeks to flee back into the womb of the one, true reality" (Geburt der Tragödie 141; Birth of Tragedy 105, trans. modified). It may be recalled that in Nietzsche's argument, traditional questions about tragedy are abolished for a conception of form resulting from two tendencies: tragedy is conceived as a collision of the Dionysian, the force of excess and originary unity; with the Apollonian, the force of form and order.

For the young Nietzsche, tragedy is the highest form of art, insofar as it combines what he takes to be the direct expression of unmediated reality in music with an Apollonian element, that is, formal structure and cohesion. In this clash of forces, however, the Dionysian ultimately retains the upper hand as the tragic plot negates the rational order and offers a glimpse at what the young Nietzsche the loyal disciple of Schopenhauer - considered the true, unindividuated reality of the will beyond all appearances. Such is for Nietzsche the truth of transgression. And yet, it is the achievement of tragedy as a form that it aesthetically transposes the horror linked to this experience into the affirmation of life, a movement that has been aptly characterized as the "suspense of transgression" (Wellbery 208). Myth, Nietzsche argues, is the decisive medium by means of which tragedy at once controls the Dionysian element through Apollonian form and ultimately effects - in the tragic conflict - the self-subversion of the rationally ordered world of appearances: in the actual destruction of the hero.

In the context of the passage, Nietzsche uses this conception in order to make two important claims about the poverty of German aesthetics. Both of them are at once extremely close to Benjamin's criticism of the Idealist legacy and yet utterly at odds with his own account. First, by claiming that tragic myth gives expression to an originary reality, Nietzsche intends to subvert the paradigm of mimesis on the most basic level. The work of the tragedian, Nietzsche argues, can "hardly be said to be the 'imitation of nature"'; rather, tragedy expresses how the Dionysian drive "consumes this entire world of appearances, allowing us to sense, behind that world and through its destruction, a supreme, artistic, primal joy in the womb of the Primordial Unity" (Die Geburt der Tragödie 141; The Birth of Tragedy 105, 
trans. modified). ${ }^{13}$ Second, Nietzsche challenges neo-Aristotelian and Idealist theories for their lack of sensitivity to this, as it were, deepest layer of meaning. "Our aestheticians," Nietzsche asserts, obviously referring to Idealist views of tragedy, Friedrich Schiller, Hegel, and company,

have nothing to report about this return to home and origin, about the brotherly bond between the two deities of art in tragedy, nor about the combination of Apollonian and Dionysian excitement felt by the listener; on the other hand, they never tire of characterizing the true essence of tragedy as the struggle of the hero with fate, the triumph of a universal moral order [Sieg der sittlichen Weltordnung], or the discharge of affects induced by tragedy [...]. (Geburt der Tragödie 141-142; Birth of Tragedy 105, trans. modified)

Benjamin accepts Nietzsche's negative characterization of the Idealist account of tragedy to a large degree, but the crucial reason Benjamin singles out section 22 is that it exposes the dependence of Nietzsche's critique on what is, ultimately, a Schopenhauerean theology of art. To the degree that Nietzsche's concepts of the Apollonian and Dionysian are in need of such an aesthetico-metaphysics to challenge Idealist theories, his critique remains inscribed within an untenable frame. Strangely located between a critique of Idealism, indeed of the entire history of philosophy, and the grandiose fantasy of panaestheticism, the young Nietzsche emerges as an ambiguous figure, already subverting the moralizing fantasies of Idealist reconciliation, yet still haunted by the all too German specters of the primal, the One, and the mythic origin. ${ }^{14}$ It is to the latter Nietzsche that Benjamin bids farewell.

And yet, why does Benjamin at first praise Nietzsche's superiority in comparison with former theories and then challenges the core of his conception? Because Benjamin claims that by conceiving of myth in terms of his aestheticism, Nietzsche "pays a high price for the emancipation from an ideal pattern [Schablone] of ethical life, which one used to impose upon the tragic action” (“Ursprung” 281). The price, Benjamin argues, that Nietzsche pays for this emancipation is the fall into the "abyss of aestheticism" (281). Why is Nietzsche's aestheticism not merely false but abyssal? It is abyssal because it makes it impossible to see myth as being in turn historically conditioned, a perspective that will be crucial for Benjamin's entire argument to follow. It is also abyssal because Nietzsche's linking of tragedy to myth - as well as his conception of the Apollonian and Dionysian as expressive of an ultimate reality - lead him to a glorification of myth and to the hope of its

13 For a useful discussion of this aspect, cf. Schmidt (197-207, esp. 204). For the alternative reading, cf. Lacoue-Labarthe, L'imitation des Modernes (126-128).

14 For a general account of Nietzsche's ambiguity, cf. Schürmann. 
return in art. Nietzsche's subversion of Idealist moralizations fully succumbs here to the hope for a new mythology, opposing Idealist aesthetics with nothing more than the nostalgic jargon of home and origin. What, asks Nietzsche, does the historical need of a dissatisfied modern culture point to, "if not to the loss of myth, the loss of a mythical home, a mythical, maternal womb?” (Geburt der Tragödie 146; Birth of Tragedy 109) No mode of thinking, Benjamin writes elsewhere as if to answer him, is "more disastrous than that which bewilderingly bends back into the myth the very thing that has begun to grow out of it" ("Goethes Wahlverwandtschaften" 163; "Goethe's Elective Affinities" 326) - whence the damnatio of Nietzsche as the $19^{\text {th }}$-century figure "in which the mythic fatality [mythisches Verhängnis] now executes itself."15

In order to distance himself from Nietzsche, Benjamin appeals to Nietzsche's nemesis, Ulrich von Wilamowitz-Möllendorff ("Ursprung” 281). He mobilizes the philologist's austerely technical definition of Attic tragedy in order to bypass the abyss of Nietzsche's aestheticism with the historically grounded thesis that tragedy originates in mythical fables, that is, in the epic tradition. ${ }^{16}$ The importance of this claim is obvious. For if tragedy originates in traditional legends, then it has a concrete historical stratum, and hence myth is a part of history, not its other, the expression of some metaphysically originary reality. Given the theory to follow, however, one cannot help noticing the deep irony in Benjamin's appeal to von Wilamowitz-Möllendorff, the arch-historicist. Benjamin was certainly aware that von Wilamowitz-Möllendorff, for whom tragedy could only be understood in the exact terms of its time, would have rejected his interpretation on the same grounds that he judged Nietzsche's exceedingly speculative book to be lacking in the "selfdenying asceticism" he deemed necessary for receiving classical antiquity in its so-called “purity” (von Wilamowitz-Möllendorff, Zukunftsphilologie! 32). ${ }^{17}$

Hence, the appeal to von Wilamowitz-Möllendorff should be seen as strategic. Benjamin needs von Wilamowitz-Möllendorff's thesis apropos tragedy's origin in mythical fables only in order to reinterpret this idea in rather different

15 Benjamin gives this characterization in a late fragment. Cf. Gesammelte Schriften (I: 1234).

16 "Wilamowitz defines: '[A]n Attic tragedy is a self-contained piece of heroic saga, poetically reworked for the enactment by a chorus of attic citizens and two to three actors, and intended for staging as part of the public worship in the sanctuary [heiligtume] of Dionysos.”' (Benjamin, “Ursprung” 284-285) Von Wilamowitz-Möllendorff develops this definition in Einleitung in die griechische Tragödie (Introduction to Attic Tragedy) which he wrote for his edition of Euripides itself a frontal assault on the tradition of 'philosophies of the tragic' and their condemnation of Euripides. Benjamin cites the text from the following, separate printing of the introduction: von Wilamowitz-Möllendorff, Einleitung in die griechische Tragödie (109).

17 For a detailed account of von Wilamowitz-Möllendorff's relation to Nietzsche, cf. Silk and Stern (95-105). 
categories. It turns out that what Benjamin means by the "historical reality" of ancient tragedy are those "historico-philosophical and religio-philosophical concepts in which the decision about tragedy's essence [Wesen] ultimately manifests itself" ("Ursprung” 283), a claim that hardly could have been to von WilamowitzMöllendorff's liking. The details of Benjamin's argument will be reconsidered below. Suffice it to say at this point that Benjamin wants to drive a wedge between his and Nietzsche's critique of Idealism in conceiving of tragedy as a "tendentious transformation" ("tendenziöse Umformung," "Ursprung” 285), of mythical legends. For Benjamin, myth is thus seen as an entirely historical phenomena, and no longer as history's other, its outside or origin. It is this level of analysis, he suggests, that Nietzsche could not reach because of his reduction of tragedy's content to what are ultimately aestheticist and metaphysical categories.

The simultaneous proximity to, and distance from, Nietzsche necessitates Benjamin's direct confrontation with Idealism. Benjamin states that Nietzsche rightly turned away from the older - that is, Classicist and Idealist - theories of tragedy, but was not able to "refute them" ("Ursprung" 283). He was unable because the early Nietzsche's aestheticism impeded him from engaging with the core of these theories, "the concept of tragic guilt and tragic atonement" (283). Benjamin's confrontation with Idealism focuses on precisely these concepts, as they define the terms and stakes for the discussion of the meaning of fate and sacrifice in tragedy. It seems superfluous even to note that this confrontation will no longer take place in the frame of either an Idealistic moralism or Nietzschean aestheticism. Hence, following on the heels of this claim, Benjamin's confrontation with Idealism is introduced by two interrelated claims, which take this proviso for granted. The first concerns the conditions of representability of the moral sphere, which in his view is illegitimately presupposed in former theories of tragedy (283-284). ${ }^{18}$ The second critique - and it is only here that Benjamin gives an actual reference for his target - concerns the illegitimacy of an interpretation that directly aims at uncovering a "moral lesson" (283) in tragedy. It is this trait which is considered as the essence of Idealist theories of tragedy (284). Both of these criticisms are subsequently unraveled by means of a reference to the most unlikely of theorists, K. W. F. Solger.

18 For an excellent discussion of this argument that locates it in the broader context of Benjamin's work, cf. Hanssen (94-97). 


\section{Prelude to a Critique: Benjamin on K. W. F. Solger}

Since Benjamin initially frames his critique of Idealist aesthetics in general terms, it is frequently claimed that his critique applies mainly to Hegel. ${ }^{19}$ This, however, is simply false given that Benjamin mentions in a letter to Scholem that he did not engage with Hegel in writing the Trauerspiel book. ${ }^{20}$ In which sense Benjamin's critique nonetheless pertains to Hegel's view of tragedy will be thematized in the subsequent section, but what needs to be discussed at first is the actual reference Benjamin himself gives in this context. This is Solger's theory of ancient tragedy, albeit Benjamin does not refer to the systematic interpretation Solger developed in his main work, Erwin, but to an essay titled "Über Sophokles und die alte Tragödie.” This text was originally written as a general philosophical introduction to ancient tragedy and served as the foreword to his 1808 Sophocles translations, Solger's first book Des Sophokles Tragödien. ${ }^{21}$ Significantly, an abbreviated form of the essay was then included in the edition of Solger's widely read posthumous writings, famously edited by Tieck and von Raumer and extensively reviewed on some 70 pages now only famous for their critique of Romantic irony - by Hegel in 1828 (Solger, "Über Sophokles" 445-492). ${ }^{22}$ It is from this edition that Benjamin quotes the text. Prior to an analysis of Benjamin's critique, it will therefore be necessary to elucidate the discursive field in which this strange text is situated.

19 Cf., for instance, Asman: "Benjamin's criticism applies primarily to German Idealist (i.e., Hegel's Ästhetik) and other nineteenth and early twentieth century theories of tragedy [...].” (620, n. 5) This argument becomes even more confused when Asman goes on to list von WilamowitzMöllendorff, who stands in direct opposition to this tradition and is affirmatively quoted by Benjamin, among these 'other theories.'

20 "It [viz. the theory of ancient tragedy] cites Rosenzweig extensively, much to Salomon's displeasure, who maintains that everything Rosenzweig has to say about tragedy can already be found in Hegel. And this may even be possible. I have not been able to go through the entire 'Ästhetik'.” See Benjamin's letter “An Gershom Scholem. 19. 2. 1925” (15); The Correspondence of Walter Benjamin 1910-1940 (261). Trans. modified.

21 The introductory essay, "Über Sophokles und die alte Tragödie," can be found in vol. I (viicii).

22 Note that this version is significantly shorter than the original one. For Hegel's review, cf. Hegel, "Solgers nachgelassene Schriften und Briefwechsel." On Solger's essay, see Walzel. The most detailed treatment of the text as well as of the context of the Sophocles translations can now be found in Baillot (38-56). Szondi actually quotes from Solger's essay at one point as well, but he treats it as completely continuous with Solger's later theory, which seems unwarranted (cf. Szondi, Versuch über das Tragische 174-176). By contrast, the literature on Solger's late theory of tragedy is vast; a useful and concise account is Decher (349-357). 
Solger's essay is indeed located in the midst of the discourse of Idealist aesthetics. Most obviously, there are several striking similarities between Solger's and F. W. J. Schelling's aesthetics, and it has commonly been assumed that Solger borrowed extensively from the latter's writings (with regard to his systematic theory of tragedy, this is also Szondi's position). However, in the discussion of symbol and allegory in early Idealist and Romantic aesthetics, it has rightly been pointed out that there is no philological evidence that Solger actually had, in the whole period prior to 1815, access to the circulating notes of Schelling's Jena and Würzbug lectures on aesthetics, which were given between 1802 and 1805 (Henckmann, "Symbolische und allegorische Kunst bei Solger" 219). Yet, whatever Solger's sources may have been, and it is ultimately of little interest, ${ }^{23}$ it is clear that he presupposes throughout the essay the basic terms of the discourse of Idealist philosophy of tragedy. The radical departure from all former theories of tragedy implied by the Idealist paradigm is not even thematized as such; it is introduced as a self-evident framework. What, if anything, defines the peculiarity of Solger's theory in this field is that his crudely schematic account brings the idolatry of the universal - characteristic for Idealist theories of tragedy in general - most sharply into view.

Solger begins his introduction by giving an abstract exposition of a dialectic between general and particular as well as between necessity and freedom, and then goes on to deduce - in keeping with the standard Idealist tripartite genre

23 Yet this much can be reconstructed with some certainty. The influence may be traced back to Solger's eventual reading of Schelling's 1795 Briefe über Dogmatismus und Kriticismus, which Solger probably knew, given that he became interested in Schelling as early as 1801 and immediately decided to study for one semester in Jena in order to hear his lectures. On this, cf. Henckmann, "Solgers Schellingstudium in Jena 1801/02." The problem with this assumption, however, is that Solger develops his philosophy of tragedy in a systematic framework, which strongly suggests at least additional familiarity with the transformation of Schelling's initial, purely metaphysical thesis into a speculative poetics, a transformation that in Schelling's work only took place in his lectures on aesthetics. Alternatively, one could track Solger's knowledge of the paradigm back to A. W. Schlegel, whose lectures, which combined and popularized ideas from his brother Friedrich and the writings of Schiller and Schelling, were instrumental in spreading the Idealist philosophy of tragedy. This thesis is supported by the fact that Schlegel's famous 1803 Berlin lectures had an immense influence on Solger's work in several respects. And there are indeed some interesting parallels between Solger's essay and the beginning of the discussion of tragedy in A. W. Schlegel (721-723; cf. 744-745). Significantly, Schlegel came to distance himself from Schlegel precisely on the question of how to understand fate in tragedy. On this, cf. Solger, "Beurtheilung der Vorlesungen über dramatische Kunst und Literatur" (396-414) and Baillot (91-102). For a general discussion of the influence of Schlegel's Berlin lectures on Solger, cf. Henckmann, “Solger und die Berliner Kunstszene.” On Schlegel's share in the spreading of the paradigm, cf. Most. 
scheme ${ }^{24}$ - the different forms of Greek literature from these principles. Accordingly, the epic is supposed to represent both principles in a unity; lyrical poetry finds its source in their difference; and it is finally Greek drama that achieves their synthesis, although Solger limits the discussion of drama to tragedy ("Über Sophokles" 453-455). Anyone familiar with Idealist aesthetics will recognize that the deductive procedure is reminiscent of Schelling. Yet in contrast to Schelling, who deliberately subordinates the literary-historical developments to the "scientific order" of his deduction, and therefore begins the a priori construction of the three genres with lyric poetry (cf. Schelling 639-659; and Szondi, Poetik und Geschichtsphilosophie 257-260), Solger tries to fit his model with the actual historical development. In opposition to Schelling, he thus relies on the Romantic and Idealist historico-philosophical developmental schema - from Homeric epic via the lyrical poets to $5^{\text {th }}$-century tragedy as their synthesis - that would become (through A. W. Schlegel's lectures and Hegel's Ästhetik) the standard model for German aesthetics and literary history in the $19^{\text {th }}$ century.

Paradigmatically, tragedy is conceived by Solger as the highest form of art since it expresses a synthesis of the particular with the general and necessary. But this turns out to be a rather peculiar synthesis, as Solger goes on to claim that it basically vindicates the superiority of the universal over and against the particular and transient, a thesis from which Solger deems himself justified in inferring tragedy's “cheerful and consoling quality” (“Über Sophokles” 456). He specifies the nature of the universal differently throughout the essay; sometimes it appears as the abstractly conceived 'Idea,' sometimes as the human 'species,' which stands against temporal and particular individuals. But the structural opposition that constitutes tragedy is consistently conceived as one between a universal principle, embodied in the divine power of fate, and a particular individual, embodied in the hero. Naturally, this opposition is aimed towards a reconciliation, a reconciliation whose site is conceived as the tragic conflict's 'resolution,' meaning the death of the hero.

For Solger, in ancient tragedy the free act of the individual thus stands in a tension with the universal, inasmuch as it is at once the condition for the possibility of the individual and potentially in opposition to her intentions. The tragic conflict is the breaking open of this potential tension, the momentary appearances of the universal as alien, and the reconciliation with it. Such is the Idealist reconciliation of tragedy: the consoling triumph of the universal. Thus, the triumph of the powers of fate is conceived as the sacrifice of the hero, which is

24 For what remains by far the best account of the emergence of the Idealist poetics of genre, cf. Szondi, Poetik und Geschichtsphilosophie. 
consoling precisely because of its demonstration of the intransient character of the universal:

At the same time at which the individual human being, who leads his isolated existence [Dasein] with lively volition, is seized and crushed by the all-mighty power of necessity [Allgewalt des Nothwendigen], the species thrives, with the everlasting and ineffaceable [unvertilgbarer] force of life, in the reverberation of the eternal laws. (“Über Sophokles” 456)

Like almost every German aesthetician around 1800, Solger singles out Sophocles as the poet who brings tragedy to its highest form. (How intense the contemporary fascination with Sophocles was can be gathered from the fact that Solger at one point feels the need to justify his publication against the current flood of Sophocles translations; cf. "Über Sophokles” 448.) In his representation of the divine powers of fate, Solger argues, Sophocles does not depict them as something threatening or frightening, but rather in such a way that they evoke "love, recognition, and trust" (460). To reveal the sheer interpretative terrorism of this analysis, it suffices to recall that this is supposed to hold true for the fate of Antigone and Oedipus, that their suffering is indeed said to evoke love and trust for the forces that destroy them. Throughout the discussion of Sophocles's 'achievement,' Solger dedicates his entire effort to integrating tragedy's dissonant elements into the general experience of consolation and reconciliatory harmony that he attributes to it. He asserts in all earnest that however much the destruction of individuals by the divine power of fate fills us with "awe and terror [Schauer und Entsetzen], we soon also feel the dignity and holiness of such an event, in which the highest and most intrinsic essence of human concerns is revealed" (468). Symbolized in the powers of fate, Solger claims, Sophocles's work expresses the highest and innermost essence of human affairs, which, for him, is of course no other than the superiority of the universal. Through the sublime and consoling representation of its power, tragedy justifies the sacrifice of the singular, reconciling its destruction within a harmonious totality. Such is, for Solger, the consolation tragedy, such is the effect that makes tragedy the highest form of art, such is the Idealist idolatry of the universal running rampant.

Compared to other Idealist philosophies of tragedy, there is an undeniable shallowness to Solger's early theory. It is the work of an epigone who uses the contemporary theory of tragedy in a crudely schematic way, a theoretical weakness that is barely covered by his monumentalizing and pathetic prose, which hardly makes for pleasant reading. The decisive question therefore is: Why did Benjamin single out this text, rather than one of the canonical works? And what is the abstract 'moral lesson' that the Idealists thus find in tragedy? Since Solger's essay is the only work Benjamin cites for the general tendency in Idealist philosophies that he seeks to criticize, the guiding assumption in the following analysis 
will be that Solger epitomizes a pattern that is prevalent in Idealist philosophies of tragedy. Solger's theory is not exemplary; it is symptomatic. In its symptomatic function, it points to a much larger discourse that Benjamin opposes and whose contours must now be traced.

\section{Elements for a Critique of Idealist Aesthetics: Solger, Hegel, Hölderlin}

The earliest articulations of the conceptual pair that organizes Benjamin's entire theory of ancient tragedy is his essay "Schicksal und Charakter" ("Fate and Character"), a text that is - in one of the rare instances of self-quotation in the book - cited at a decisive point in the discussion of tragedy in the Trauerspiel book ("Ursprung” 288-289). Structurally, this essay begins with the semantic assumption of a mutual dependence of fate and character and then elaborates their disjunction. The figure of disjunction is, then, transposed into the theory that Benjamin develops in the Trauerspiel book, where tragedy is understood, no longer as the restrictive disjunction of character and fate, but as a general opposition to myth and sacrifice. As will become obvious in the course of the analysis, this disjunctive understanding of tragedy is likewise at the heart of Benjamin's critique of Idealist philosophies of the tragic. The reading that follows will therefore transition between "Fate and Character" and the theory of ancient tragedy in the Trauerspiel book, alternating between the texts to reveal their conceptual dependence. In so doing, it will become increasingly necessary to follow Benjamin's direct and implicit references to Idealist aesthetics, as it is only in this movement that Benjamin's critique - relying as it does on the construction of a complex frame of reference - can be brought to light.

In Benjamin's terminology, 'fate' is one specification of his general concept of myth, which in turn numbers among the most overdetermined notions in Benjamin's work as a whole - whence the continuity between the early essay and the theory of ancient tragedy. Yet, as with so many of his key concepts, Benjamin never gives an exposition of 'myth,' but only unfolds it through an engagement with a concrete object of inquiry, hence in thematically very specific contexts. These highly specific uses, however, in turn signal that Benjamin presupposes a more general, if not systematic, theory which only surfaces in each of the specific instances. This conceptual strategy may be due to the fact that Benjamin considered it unfeasible, as he put it in a letter to Hofmannsthal where he comments upon Cassirer's work on myth, "not only to attempt to present mythical thought in concepts - that is, critically - but also to illuminate it adequately in contrast 
with what is conceptual." ${ }^{25}$ Hence, an abstraction from the different contexts in which Benjamin uses the concept is both illegitimate and necessary.

Broadly put, Benjamin always thinks of myth in relation to history, where the concept denotes impediments to human life, thought, and action in specific contexts. ${ }^{26}$ Benjamin links 'myth' - as well as its correlates like 'fate' and 'the demonic' - to blind forces that are beyond political control, forces that are thus inextricably tied to the notion of guilt and sacrifice. It is for this reason that Benjamin calls the demand of sacrifice - in the context of a critique of no other than Solger's Goethe interpretation - the "mythic archetype" ("Goethes Wahlverwandtschaften" 140; "Goethe's Elective Affinities" 309). To the extent that myth manifests itself in forms of oppression, Benjamin defines his own stance emphatically, indeed furiously, in opposition to myth. In its most extreme form, this is famously phrased as the need to "forge ahead with the whetted axe of reason, looking neither left or right," in order to "clear the entire ground and rid it of the underbrush of delusion and myth" (Das Passagen-Werk 570-571; The Arcades Projects 456-457). But, as Adorno was the first to point out - and as one still has to emphasize against the dominant reading that takes Benjamin to be but a rationalist or theologic critic of myth - his radical opposition has a dialectical moment, inasmuch as he links the break with myth, the organizing aim of several strands in his writings, in a final complication to the notion of rescue (Adorno 244). Benjamin, always the dialectician without mediation, construes the destructive critique of myth as the only possible means for its redemption.

In this perspective, Benjamin's earlier claim that tragedy originates in mythical fables and that it has to be understood as their "tendentious transformation" ("Ursprung" 285) begins to become legible. Benjamin needs the claim that tragedy originates in mythical legend in order to locate it historically, thus making it possible to construe tragedy as an engagement with the historical reality of myth. Whence the aversion to Nietzsche's aesthetico-metaphysics. If myth mediated a metaphysically originary reality, then myth would indeed be tragedy's essence and the form could hardly be the transformation of it. This is the idea behind Benjamin's claim that "if myth is, for the poet, the tribunal [Verhandlung], then

25 See Benjamin’s letter “An Hugo von Hofmannsthal. Berlin, 28. 12. 1925” (106); “To Hugo von Hofmannsthal. Berlin, December 28, 1925” (287). Trans. modified. For a discussion of the context of this important passage, cf. Mali (176).

26 Given the importance of the concept of myth in Benjamin's work, it is rather surprising how few substantial works in the massive secondary literature have been dedicated to the topic. Far and away the best study remains Menninghaus, Schwellenkunde (10-25, 67-92). From the more recent interpretation, Eric L. Santner's psychoanalytical reading stands out, developed in his On Creaturely Life (65-67). 
his work is at once the representation [Abbildung] and revision of it” (295). Insofar as tragedy 'lives off' the plot structures and imagery of mythical fables, it is a representation of myth; but in its historical tendency, tragedy is the revision of myth, a struggle against myth's tantalizing and oppressive manifestations. For Benjamin, tragedy is the destruction of myth from within, its immanent subversion and historical revision.

Further, since myth is entangled with the demand of sacrifice, tragedy - as the representation and revision of myth - is at once based upon sacrifice and the announcement of its end. "Tragic poetry," writes Benjamin, "is based upon the idea of sacrifice [Opferidee]. But in its object - the hero - the tragic sacrifice [Opfer] is different from any other, since it is a last and first sacrifice at once." (285) The intricate modality of the anticipatory aspect of Benjamin's theory of tragedy will be discussed at the very end of this essay. Suffice it to say at this point that Benjamin accepts the link between tragedy and sacrifice - a common assumption in German aesthetics at least since Johann Christoph Gottsched and one that haunts, as will be shown in still more detail below, the entire Idealist discourse ${ }^{27}$-, yet he does so only in order to conceive tragedy as the revision of this very idea. For Benjamin, tragedy is constitutively intertwined with sacrifice, but in its own inner dynamic, tragedy twists free from its origin and renders it inoperative.

Benjamin's conception of tragedy as a break with myth has a second dimension, a subtext, as it were, that formulates his most thorough critique of the Idealist philosophies of tragedy. The central concepts that structure these subtexts are 'character' and 'genius,' concepts that Benjamin uses interchangeably. These are radically political notions, inasmuch as they have no recourse to subjective individuality or interiority, but rather refer to human singularity in relation to myth. In line with this, Benjamin argues that the hero - who takes the role of 'character' - can be both the victim of mythical sacrifice and an announcement of its end. This is because her death - despite its sacrificial character - takes the form of a rebellion: the act that initiates the emancipation of 'character' from the context of myth and fate. However, since this resistance is a singular act, and since it is renounced by the community, it "remains speechless" (288). The hero is bereft of speech, yet this deprivation takes a peculiar form, as it is, essentially, the hero's withholding of speech in the face of sacrifice. What is, thus, vindicated is what Agamben describes as the "abyss of human impotentiality," as the hero is precisely "in relation to [...] [her] own privation" (Agamben, "On Potentiality"

27 For an informative yet entirely uncritical overview of the discourse about tragedy and sacrifice from Gottsched onward, cf. Alt (30-39). 
182-183, italics G. A.). The hero's silence - her "moral speechlessness" - is the specific relation that the hero takes towards her own privation: the withholding of her capacity of speech in the name of different forms of speech, of a language that is not yet. For Benjamin, humanity's first rallying cry against myth must therefore be silent. A silent revolt, a revolt of silence. An act of impotentiality.

The germ of this idea can be found in "Fate and Character" and Benjamin quotes the decisive passage at length in the Trauerspiel book:

Happiness is, rather, what releases the fortunate man from the embroilment of the fates and from the net of his own fate. Not for nothing does Hölderlin call the blissful [seligen] gods 'fateless' [schicksallos]. [...] It was not in law but in tragedy that the head of genius lifted itself for the first time from the mist of guilt, for in tragedy demonic fate is breached. But not by having the endless pagan chain of guilt and atonement superseded by the purity of the man who has expiated his sins, who is reconciled with the pure god. Rather, in tragedy pagan man becomes aware that he is better than his god, but the realization robs him of speech, remains silent. [...] There is no question of the 'ethical world order' being restored ['sittliche Weltordnung' wieder hergestellt werde]; instead, the moral hero, still dumb, not yet of age - as such he is called a hero - wishes to raise himself by shaking that tormented world. The paradox of the birth of genius in moral speechlessness, moral infantility, is the sublimity of tragedy. It is probably the basis of all sublimity, in which genius, rather than God, appears. - Fate shows itself, therefore, in the view of life, as condemned, as having essentially first been condemned and then become guilty. (Walter Benjamin, "Schicksal und Charakter" 174-175; “Fate and Character" 203-204, trans. modified ${ }^{28}$

This passage stands in a complex relation to the discourse of Idealist philosophies of tragedy. To begin with, the reference to there being no question of a restoration of the "sittliche Weltordnung" is an obvious polemic against Schiller and his ilk and a direct reference to Nietzsche. More important for the current discussion, however, is the reference to Hölderlin's term 'schicksallos' (or, in Hölderlin's own orthography, 'schiksaallos'). This is a rather striking reference, genuinely living up to Benjamin's demand that a quotation ought to wrench a word "destructively from its context” ("Karl Kraus" 363). The term 'schicksallos' occurs in two famous passages in Hölderlin's work, both of which formulate an idea of fate that indeed stands in direct opposition to Benjamin's appropriation. The first occurrence, the one from which Benjamin quotes the term, is Hölderlin's Hyperion, where it appears at the beginning of the second stanza of the so-called "Schicksallied" ("Song of Fate"), a poem that Hyperion attaches to one of his letters to Bellarmin. In the context of the poem, the first two stanzas describe the eternal and blissful being of the gods. Of them, Hölderlin writes, in the second stanza: "Schiksaallos, wie der schlafende / Säugling, athmen die Himmlischen; / Keusch bewahrt / In

28 This passage is partly cited in "Ursprung" (288-289). 
bescheidener Knospe / Blühet ewig / Ihnen der Geist, / Und die seeligen Augen / Blicken in stiller / Ewiger Klarheit." (Hyperion 143) ("Fateless the Heavenly breathe / Like an unweaned infant asleep; / Chastely preserved / In modest bud / For ever their minds / Are in flower / And their blissful eyes / Eternally tranquil gaze / Eternally clear.") ${ }^{29}$

The third stanza, however, in one of the radical breaks characteristic of Hölderlin's work, abruptly moves to a consideration of human life, which is lived in radical and desperate separation from the gods. Of human life, Hölderlin writes: "Doch uns ist gegeben, / Auf keiner Stätte zu ruhn, / Es schwinden, es fallen / Die leidenden Menschen / Blindlings von einer / Stunde zur andern, / [...]." (But we are fated / To find no foothold, no rest, / And suffering mortals / Dwindle and fall / Headlong from one / Hour to the next, / [...].) Here, the realm of human life - transient, finite, and alienated from the divine - is necessarily the place where one cannot be 'schicksallos,' where fate is inevitable.

What is more, Hyperion is constructed in such a way that the poem, which marks the highest point of Hyperion's desolation after Diotima's death, is integrated into a development that qualifies and sublates this dualism. Structurally, the function of the poem is to state the highest dissonance that is then resolved in the course of the work. The lamentations about the radical separation from the divine and the unending sorrow of finite existence are integrated into a process of remembrance and reflection that are oriented toward reconciliation. Indeed, the novel as a whole ultimately calls all dualisms that run through it into question. A famous line at the end of the novel states this most emphatically: "Versöhnung ist mitten im Streit und alles Getrennte findet sich wieder." (Hyperion 160) ("Reconciliation is in the midst of strife, and all things that are parted find one another again," Hyperion 133, trans. modified.) The radical separation that underwrites the "Schiksaallied" is thus called into question and an approximation of opposites is called for. With regard to a conception of the divine, the novel thereby prepares a development that comes to the forefront slightly later in Hölderlin's work.

It is well known that Hölderlin eventually discarded the dichotomy between the temporal and the eternal, which made the idea of 'fatelessness' thinkable as a contrast, and conceived of the absolute itself as something entirely temporal. Thus, Werner Hamacher and Anja Lemke, among others, traced the genesis and modality of a genuinely temporal understanding of the divine in Hölderlin's work (Hamacher, "Parusie, Mauern"; Lemke). From now on, the gods as well are

29 In this and in the next quotation, Michael Hamburger's separate translation of the poem is cited, which can be found under the title "Hyperion’s Song of Fate” (65). 
affected by fate. The most explicit and condensed formulation of this thought occurs in the hymn "Friedensfeier": "Denn längst war der zum Herrn der Zeit zu groß / Und weit aus reichte seine Feld / wann hats ihn aber erschöpfet? / Einmal mag aber ein Gott auch Tagewerk erwählen / Gleich Sterblichen und theilen alles Schiksaal. / Schiksaalgesetz ist diß, daß Alle sich erfahren, / [...]." (535) ("For long now he had been too great to rule / As Lord of Time, and wide his field extended, but when did it exhaust him? / For once, however, even a God may choose / Mere daily tasks, like mortals, and share all manner of fate. / This is a law of fate, that each shall know all others, / [...]," "Celebration of Peace" 461). While the stanza at first seems to restate the aforementioned dualism by appealing to an atemporal and transcendent conception of the divine (the "Lord of Time"), the following lines signal that divine 'transcendence' has to be conceived as something immanent to time, inasmuch as by 'choosing' daily tasks, the divine becomes mundane and temporal. The absolute is the "Lord of Time," not because it is above and beyond time, but rather because it is nothing but time. The radical separation and alienation of the Schicksallied is substituted by the "law of fate, that each shall know all others." In time, that is, the human and divine come to know each other. Blissfulness, it would seem, for the early Hölderlin only possible under the law of fate.

Yet there is a second sense in which Hölderlin uses the term 'schicksallos,' and this usage occurs in another text of Hölderlin's that Benjamin knew very well. In the third part of "Anmerkungen zur Antigonae," Hölderlin differentiates modern from ancient tragedy by specifying what they respectively lack 'naturally' and hence need to acquire 'artificially.' Playing on the link between 'Geschik' (skill) and 'Schiksaal' (fate), Hölderlin writes that modern tragedy is in need of technical skills, "since the lack of fate [das Schiksaallose], the $\delta v \sigma \mu o \rho o v$, is our weakness." ("Anmerkungen zur Antigonae" 270; "Remarks on "Antigone”" 114, trans. modified). Modern culture, Hölderlin argues, lacks a sense of fate, which is why modern tragedy must compensate for this by means of its technical innovations. In the context of the "Anmerkungen," Hölderlin associates the givenness of fate in Greek tragedy with epochal tensions that befall the tragic hero, tensions that are experienced as a destructive force of nature. These epochal tensions crystallize in historical crises - turnings of time - and it is in these moments that the absolute manifests itself in an individual. The form this manifestation takes is, of course, the tragic hero's death, her sacrifice. In “Grund zum Empedokles," Hölderlin asserts explicitly that the fate of an epoch demands nothing but a "sacrifice" ("Opfer") in the person of the tragic hero ("Grund zum Empedokles" 157; "The Ground for Empedocles" 56, trans. modified).

Hölderlin's use of the term 'schicksallos' is indeed deeply linked to his discussions with Hegel during their time in Frankfurt, in which tragedy figured as 
one of the central topics. The discourse on fate and sacrifice, therefore, cannot be disentangled from the Idealist dialectics. Little wonder, then, that the noun corresponding to 'schicksallos' occurs in one of Hegel's texts from this period, an essay he wrote immediately after he left Frankfurt for Jena. This text is the Natural Law essay, in which Hegel tries to analyze the development of ethical life using the model of tragedy. Hegel's use of the term differs from Hölderlin's, insofar as he associates fatelessness with an inauthentic development of ethical life, yet this use as well directly leads to the theme of fate and sacrifice. In Hegel's work, the term is reversed for tragedy's other, comedy:

Tragedy consists in this, that ethical nature segregates its inorganic nature (in order not to become embroiled in it), as a fate, and places it outside itself; and by recognizing [durch die Anerkennung] this fate in the struggle against it, ethical nature is reconciled with the Divine being as the unity of both. To continue this metaphor, Comedy, on the other hand, will generally come down on the side of fatelessness [Schicksallosigkeit]. (G. W. F. Hegel, "Über die wissenschaftlichen Behandlungsarten des Naturrechts" 496; The Scientific Ways of Treating Natural Law 105, trans. modified)

Here, it begins to transpire how Hölderlin and Hegel's ambiguous stance toward a lack of fate leads to the heart of their shared understanding of tragedy, inextricably tied in turn to their understanding of dialectics. Indeed, it will increasingly become apparent that at the very basis of this dialectic lies the idea of sacrifice, a sacrifice that appropriates the negativity of the hero's death through fate, through, that is, her relation to the universal. And with this, a point of the investigation is reached where the philological reconstruction must give way to an analysis of a broader constellation in the Idealist discourse, even though it can be easily demonstrated that Benjamin knew enough of the texts under discussion to have a grasp of them. ${ }^{30}$ It was from 1798 onward that Hegel's and Hölderlin's

30 Benjamin in all likelihood did not read Hegel's writings from this period, which were edited and published for the first time by Herman Nohl in 1907. In 1919, when he wrote "Fate and Character," he was, however, already certainly aware of the most important texts of Hölderlin in this context. According to Scholem, Benjamin was interested in Hölderlin's work by the time he met him and that he was using the Insel edition (edited by Franz Zinkernagel). Hence Benjamin had access to all relevant texts by the time he wrote the essay. Cf. Hölderlin, Sämtliche Werke und Briefe; Scholem (23). Cf. also Jennings (98-104, 190-195). For the period leading to the Trauerspiel book, an immersion in Hölderlin's work is evident, as Benjamin was among the first thinkers to recognize the seminal importance of Hölderlin's “Anmerkungen zum Oedipus.” Moreover, the preparatory notes for the theory of ancient tragedy in the Trauerspiel book even envisage an engagement with Hölderlin's Sophocles translations. Cf. Benjamin, “Goethes Wahlverwandtschaften” (181-182); “Goethe’s Elective Affinities” (340-341). For the remark on Hölderlin in the preparatory notes, cf. Gesammelte Schriften (I: 917). 
discussions of tragedy began to gravitate around the notions of fate and sacrifice, themes that would prove instrumental for their subsequent theorizing in several respects. ${ }^{31}$ Naturally, in the wake of Lacoue-Labarthe's influential reading, it has become a familiar move to drive a wedge between Hölderlin and Hegel on the question of tragedy, portraying Hölderlin as the counter-figure to the machinery of Idealist dialectics (Philippe Lacoue-Labarthe, "La césure du spéculatif"; cf. also Métaphrasis 30-42). There is much to be said for this reading, and Benjamin was indeed attracted to precisely those elements in Hölderlin's theoretical writings that are highlighted by Lacoue-Labarthe and his followers. But for the theme discussed here - the link between fate and sacrifice - no break between Hegel and Hölderlin can be discerned..$^{32}$ Even a cursory reading of "Grund zum Empedokles" establishes this beyond any doubt. All tragic individuals, writes Hölderlin,

who in their characters and utterances are all more or less attempts to solve the problems of fate [Schicksal], and who are sublated [aufgehoben] to the extent that they are not universally valid unless, on the other hand, their role, their character and its utterances present themselves as something transient and momentary, so that the one who seemingly solves fate [Schicksal] most completely also presents himself most clearly in his transitoriness and, in the progress of his attempts, most evidently as a sacrifice [Opfer]. ("Grund zum Empedokles” 157; “The Ground for Empedocles” 57, trans. modified)

\section{And thus the}

fate of his [viz. Empedocles] epoch, the tremendous extremes out of which he grew, did not demand a song where the pure is still easily conceived in an Idealistic presentation [...] it demanded a sacrifice where man in his entirety becomes real and visible as that wherein the fate of his epoch seems to dissolve. (“Grund zum Empedokles” 157; "The Ground for Empedocles” 56, trans. modified)

What one sees surfacing here is the irreconcilable tension between Benjamin's theory of tragedy and the philosophical accounts of Idealist dialectics - even in the form of Hölderlin's thought, which marks its edge, the boundary where it begins to

It should also be noted that Szondi (Versuch über das Tragische 203) was the first to link Benjamin's theory of ancient tragedy to Hölderlin's “Grund zum Empedokles,” correctly insisting on the shared interest in sacrifice. However, Szondi does not see a possible tension between the two and goes as far as to assimilate Benjamin's theory to Hölderlin and Hegel. Consequently, Szondi does not even mention Benjamin's critique of Idealist philosophies of tragedy.

31 On fate and sacrifice in Hegel's and Hölderlin's understanding of tragedy during this period, cf. Billings, Genealogy of the Tragic (ch. 5, esp. 139-158). The most detailed account of the Frankfurt discussions is Christoph Jamme.

32 Françoise Dastur (54-61), whose interpretation is rather close to Lacoue-Labarthe's, even suggests that Hölderlin takes a more drastic stance with regard to these themes. 
disintegrate. For Hegel and Hölderlin, just as for Solger, 'fate,' in its relation to sacrifice, is the central category by means of which tragedy can be understood; it is the mediation that neutralizes and appropriates the negativity of the hero's death for the universal. That Benjamin conceives of tragedy in terms of 'fatelessness' and as the end of the order of sacrifice is anything but accidental. Naturally, within the Idealist discourse, the details of the concept of 'fate' differ tremendously between Hegel, where 'fate' stands in an intrinsic relation to the hero's actions, and Solger or even Schelling, where it denotes an external necessity. But what unifies these differences is the structural similarity of a pattern that Benjamin targets with his critique: Idealist philosophies of tragedy understand fate in terms of the sacrifice of the singular for the sake of the universal. The Idealist philosophies of tragedy are, therefore, critiqued by Benjamin as a false aesthetic of consolation, as a justification of the hero's sacrifice, a celebration of suffering in the name of the universal, in short, as an idolatry of the universal. It is precisely this understanding of tragedy against which Benjamin's understanding of the silence of the hero as a form of acknowledgement of what is thus renounced - the singular - is aimed.

It suffices to track the conceptual chain of fate, sacrifice, and reconciliation in the different texts to bring this to view. "Fate," writes Hegel, "puts individuality back within its limits and crushes [zertrümmert] it if it has dared to cross them [sich überhoben hat]." (Ästhetik 548; Aesthetics 1216, trans. modified) In this way, fate effects tragedy's reconciliation of opposites, which find their concretization in tragic individuals that embody justified but one-sided claims. For "if the onesidedness is to be sublated [aufgehoben]," writes Hegel, "it is the individual, since he has acted solely as this one 'pathos,' who must be sloughed off [abges-

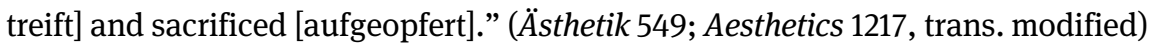
In a barely concealed move, Hegel effects here, with a chain of German verbs starting with 'a' - “aufgehoben," “abgestreift” and "aufgeopfert” -, a direct transition from dialectical sublation to factual sacrifice. Thus, in Greek tragedy, "it is eternal justice which, as the absolute power of fate, saves and maintains the harmony of the substance of the ethical order against the particular powers which were becoming independent and therefore colliding, and because of the inner rationality of its sway [Walten] we are satisfied when we see individuals coming

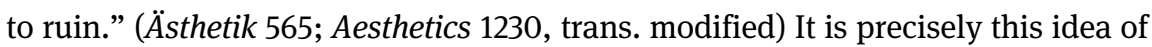
fate that Benjamin attacks when he writes that fate portrays life "as condemned," and condemned it is here by the false totality of Idealism.

For however much Hegel may struggle to mediate the universal and the particular dialectically in his other writings, in his account of tragedy he opts for a despotism of the universal, and indeed ruthlessly so. The same holds for Solger. It has already been noted that, for him, the importance of tragedy consists precisely in its glorification of the powers of fate, which sacrifice the individual to 
show the superiority of the universal, thus allegedly evoking "love, recognition, and trust” (“Über Sophokles” 460). About the hero’s death, Solger asserts, again in all earnestness, that it

is not merely the destruction of an individual human being, but rather the most complete reconciliation [Versöhnung] of the contradiction that tears him apart. His death leads our gaze from this world, which is never at one with itself, to the abyss of holiness [Abgrund der Heiligkeit], in which time and eternity meet again and unite most intimately. (469)

Fully succumbing to his philosophico-hermeneutical delusions, Solger argues that the destruction of the individual is transfigured into a consolation because, in his sacrifice, the individual "is stamped by the seal of the eternal" ("das Siegel des Ewigen aufgedrückt wird," 468). Thus the misery of Idealism reigns supreme. But with this, the radical opposition between Benjamin's theory and the Idealist philosophies of tragedy can come plainly into view.

In direct opposition to this discourse, Benjamin holds that the hero's death signifies, not, as Solger claimed, "the victory of the eternal might of holy law" (468), but rather the "subversion of the ancient laws [alten Rechtsverfassung]" (Benjamin, "Ursprung” 294). Tragedy, writes Benjamin, "which seemed intended as a tribunal [Gericht] over the hero turns into a negotiation [Verhandlung] over the Olympian gods," that is, into a revision of myth and fate (288). For Schelling, the philosopher most famous for his notion of the tragic sublime within the discourse of Idealism, the sublime consists, precisely, in the hero's free acceptance of a punishment due to an undeserved guilt, a guilt that has indeed been "imposed by fate" ("durch das Schicksal verhängt," Schelling, Philosophie der Kunst 699, 697)..$^{33}$ For Benjamin, again in direct opposition to this paradigm, tragedy's sublimity turns into the resistance against fate and the hero's "bearing witness to speechless suffering" ("Ursprung" 288). Whereas the Idealist philosophies seek a justification for the sacrifice of the individual in the name of a universal order, the thrust of Benjamin's theory is the subversion of the order which is supposed to be justified.

A final complexity about Benjamin's relation to the Idealist discourse is that the figure of an 'interruption' of fate in the Trauerspiel book stands in a complex relation to Hölderlin's notion of the caesura, understood both in the traditional sense of a counter-rhythmic interruption and in Hölderlin's specific sense as a generic element in ancient tragedy. In his 1921 essay on Goethe, which falls in the period between "Fate and Character" and the Trauerspiel book and thus sheds light on the development of the ideas under discussion, Benjamin links the

33 On the genesis of this notion of fate in Schelling's writings on tragedy, cf. Ferris (96-101). 
silence of the hero to his notion of the expressionless. The expressionless is a nonintegrable remnant within an artwork, a remainder that turns against, fragments its wholeness, and exposes its semblance character. It is a critique of beauty through the sublime. ${ }^{34}$ Thus Benjamin writes that the expressionless "shatters whatever still survives as the legacy of chaos in all beautiful semblance: the false, errant totality - the absolute totality. Only the expressionless completes the work, by shattering it into a thing of shards, into a fragment of the true world, into the torso of a symbol" (Benjamin, "Goethes Wahlverwandtschaften" 181; “Goethe’s Elective Affinities” 340). After a long citation from Hölderlin's “Anmerkungen zum Oedipus" on the caesura as the moment in which "every expression simultaneously comes to a standstill, in order to give free reign to an expressionless power inside all artistic media," Benjamin immediately adds: "Such power has rarely become clearer than in Greek tragedy, on the one hand, and in Hölderlin's hymnic poetry, on the other. Perceptible in tragedy as the silence of the hero, and in the rhythm of the hymn as interruption [Einspruch, which can also translate as intervention or objection]." ("Goethes Wahlverwandtschaften" 182; "Goethe’s Elective Affinities” 341, trans. modified)

Significantly, Benjamin here mobilizes an element from within the Idealist discourse against this discourse. What thus becomes evident is how Benjamin's focus on the silence of the hero reacts against theoretical attempts to transfigure dissonant elements into a fully integrated whole, where the totality of the work corresponds to the totality of the universal. The understanding of the hero's silence as the expressionless, modeled as it is on the idea of the work-immanent destruction of "all beautiful semblance," is his attempt to focus on the tragedy's negativity in such a way that transfiguration and reconciliation are undercut. These elements - the opposition to totality and the insistence on singularity - are then further elaborated by Benjamin in the Trauerspiel book with reference to another writer who decisively turned against Idealism: the philosopher and theologian Franz Rosenzweig.

\section{Silence and Singular Bodies}

It is Franz Rosenzweig's Stern der Erlösung, a book that has becomes famous for its critique of Idealism, with which Benjamin aligns himself most closely in his own theory of tragedy. Indeed, Benjamin quotes from precisely that section of the

34 The single best text on the concept remains Winfried Menninghaus's "Das Ausdruckslose: Walter Benjamins Kritik des Schönen durch das Erhabene.” 
book which has been described as one of the most decisive examples for Rosenzweig's turn away from Idealism, the section on the 'meta-ethical' self (cf. Rosenzweig, Stern der Erlösung, part 2, book 3). ${ }^{35}$ This concept is Rosenzweig's attempt to come to terms with the dimension of singularity, which he saw as entirely unacknowledged in German Idealism, the philosophical tradition in which he received his philosophical education. The prefix 'meta-' has to be understood as marking that part of an individual which exceeds the general order that is otherwise constitutive of its being. As in Benjamin, this understanding of singularity is opposed to any idea of subjective interiority, insofar as it operates on a structural level. In contradistinction to an individual's subjective 'personality,' which marks its inscription in the order, Rosenzweig renders this singular aspect of a human being its 'meta-ethical self' or 'character.' Thus, 'personality' describes the generic part of a human being, those aspects of her that can be expressed propositionally, and hence are subsumable under general concepts (74). By contrast, the 'character' or 'meta-ethical self' is the remnant that resists generic identification. From the point of view of the universal, it marks the individual's uselessness, her pure and contingent arbitrariness; it is, as Eric L. Santner puts it, "a gap in the series of identifications that constitute it" (On the Psychotheology of Everyday Life 73, italics E. S.).

Rosenzweig himself was not interested in developing a free-standing theory of tragedy, but he saw in the tragic hero the exact embodiment of his notion of singularity. For Benjamin's project, however, this notion is decisive, as it stands in a terminological and systematic continuity with the view of tragedy first explored in "Fate and Character." And the convergence is striking indeed. The essay "Fate and Character" was written between mid-September and November $1919,{ }^{36}$ and then published in the journal Die Argonauten in 1921, the very same year in which the first edition of Rosenzweig's Stern der Erlösung went into print. It has been noted above that 'silence' is the central category for Benjamin's understanding of the hero's break with fate in this essay. And it is from this perspective that the passage from Rosenzweig's work that Benjamin quotes in the Trauerspiel book should be read:

For that is the distinctive sign of the Self, the seal of its greatness, and the mark of its weakness: it is silent. The tragic hero has only one language that completely corresponds to him: namely, silence. Thus it is from the beginning. Precisely for this reason, the tragic [das Tragische] forged for itself the aesthetic form of drama, which allows the representation of silence [...]. By being silent, the hero breaks the bridges that link him to God and the world,

35 On Rosenzweig's relation to German Idealism, cf. Gordon (chs. 2-3).

36 On the dating of the essay, cf. the editor's note in Gesammelte Schriften (II: 940-942). 
and elevates himself from the landscapes of personality, which, through the spoken word, marks out its limits and individualizes itself in the face of others in order to climb into the icy solitude of the Self. How else is it to manifest its solitude within itself, this rigid defiance, other than by being silent? (Rosenzweig, Stern der Erlösung 83-84; The Star of Redemption $85-86$, trans. modified $)^{37}$

With regard to the historical reality of Greek myth, the silence signifies the hero's rebellion against the old order, which, as mythic, is the suppression of human singularity and the possibility of political action. The silence epitomizes tragedy's historical reality, as it is in the wake of tragedy, that the old gods of the mythic world finally begin their descent ("Ursprung" 288). Since, however, this protest remains singular, since the hero is disowned by the community, and since she has no language to articulate her rebellion, the protest has to remain "silent" (287). A silent revolt, a revolt of silence. A revolt in which the singular opposes the order of myth with nothing but impotentiality, the refusal of the language of the 'until now.' This is, for Benjamin, the strength of the hero's weakness, the act of impotentiality. It is the revolt of tragedy, its sublimity: "The paradox of the birth of genius in moral speechlessness, moral infantility, is the sublimity of tragedy." ("Schicksal und Charakter" 174-175; "Fate and Character" 203-204, trans. modified) ${ }^{38}$

In conceiving of human singularity as marking the center of tragedy, both Benjamin and Rosenzweig stand in direct opposition to the Idealist discourse. "Drama," Solger writes in the discussion of Goethe's Elective Affinities (which Benjamin knew well as he severely critiques it in his own essay on the novel), "is the truest presentation of the species as the first-born and of the individual as the second" (Solger, "Über die Wahlverwandtschaften" 177). Both Rosenzweig's and Benjamin's notion of singularity as a remnant that cannot be recaptured by the economy of the universal and particular wreck havoc on this Idealist machinery. Yet Benjamin adds a materialist inflection to Rosenzweig's idea of the hero's silent rebellion when he conceives it as a retreat to the body, to what he names the "physical self" ("Ursprung" 287). This conceptual link is also important for understanding that Benjamin's notion of the tragic sublime radically parts ways with any aesthetic subjectivism, since it is the body, the "physical self," that carries it. Indeed, the tragic hero is "soulless," her interior nothing but an "immense void," $(287,293)$. And in her immersion into pure physicality, in her retreat from language, meaning is not found but disrupted: "Not language, only [her] physique" (287) is what animates the hero's relentless resistance. There is no ascent to some

37 On the tragic hero's systematic role in Rosenzweig’s Star, cf. Mosès, Système et Révélation (6774).

38 This, again, is the passage quoted in Benjamin, “Ursprung” (288-289). 
higher truth, but a movement downwards, down to a zero degree of signification where nothing remains but the experience of bodily suffering, a consummate negativity that cannot be recuperated for the sake of a larger whole, a totality of meaning. Beholden we may be to tragedy, but not to its edifices. Beholden we are to its disruptive power. It is, for Benjamin, an experience that breaks.

In the speechless suffering of the hero, a non-signifying element - the expressionless - emerges, which tears the totality of any reconciliation to pieces. As an expressionless gesture, the hero's silence - her sublimity - is a being "beyond all beauty," an experience beyond aesthetics, an anti-aesthetic of bodily singularity (Benjamin, "Goethes Wahlverwandtschaften" 196; "Goethe’s Elective Affinities" 351). The shift that is fully effected only here is a disruption of the Idealist transfiguration of tragedy's dissonance into a harmonious whole. Instead of deriving meaning from the hero's death, the totality is fragmented as the negativity of the hero's suffering is conceived as the shattering of tragedy's meaning.

Although Benjamin characterizes the temporal structure of this notion of the sublime in terms of anticipation and prefiguration, he refrains from any more detailed specification. Indeed, the only phrasing he offers appears as a deliberate paradox since he establishes a link between the hero's silence and a future language. The silence of the hero, Benjamin writes, speaks of "a coming justice" ("Ursprung" 292). Indeed, the "further the tragic word remains behind the situation [...] the more the tragic hero has escaped the ancient laws" (287-288). Such is Benjamin's paradox. The more radically the silence breaks with the old order, the further it points towards a new language, a language that first articulates itself in the breach of silence. But what else could it be that marks the 'after' of the ancient law? What is found "after the law," Agamben reminds us, "is not a more proper and original use value that precedes the law, but a new use that is born only after it" (State of Exception 64). The disruption of silence is not a return to home and origin, but the anticipation of a new use, a coming language. Yet it can only do so as a void, as an interruption of the 'until now,' the permanent catastrophe: this is why it escapes the old laws the more it exiles itself from the meaning that is.

One more question needs to be settled. Since Benjamin at one point calls the silence of the hero an early form of prophecy, it has frequently been argued that the object of these anticipations is monotheism. ${ }^{39}$ Alas, a curious religion this would be, one that announces itself as the absence of meaning. In this, the most reductionist reading, all elements supposedly fall neatly in their place, as the

39 The most flagrant case of this misreading is Bohrer, Der Abschied (503-506); repeated in Bohrer, Das Tragische (20-24). Also cf. Rochlitz (108). For a fine handling of the subject, one that does not misread the notion of prophecy in terms of teleology, cf., however, Fenves. Also cf. the treatment of prophecy in Hamacher, “NOW': Walter Benjamin on Historical Time.” 
whole attack on Idealist aesthetics is ultimately portrayed as succumbing to a theological and reconciliatory reading of tragedy. Yet the utter absurdity of this interpretation is already apparent in that it attributes a teleological philosophy of history to Benjamin, the view he opposed from his earliest writing onwards. What the actual content of 'prophecy' is, however, can only be understood once its role in Benjamin's reflection on the notion of history is considered. In the parilopomena to his final word on the subject, Benjamin asks, "Could prophecy and critique be the categories that come together in the 'rescue' of the past?" (Gesammelte Schriften I: 1245) That prophecy partakes in the rescue of the past - the only place where it can merge with critique - depends on the role Benjamin attributes to it in the production of the present, of historical time in the genuine sense: "There is a concept of the presence according to which it forms the (intentional) object of a prophecy. This concept is the (complement) correlate to a notion of history that comes into appearance like a flash. It is a radically political concept [ein von Grund auf politscher] [...].” (1234)

Thus the actual, namely the radically political implication of the linkage of silence, language, and prophecy, becomes transparent. It is precisely of this present that Benjamin writes: "[it] is not transition but that in which time halts [einsteht], in which it has come to a standstill. This present [...] is the object of a prophecy." (1250) Present in the genuine sense can only be that moment which effects this movement and thereby fulfils the past. The withholding of speech in the hero's silence is a language, indeed a prophetic language, but only insofar as the intention of this asemantic speech disrupts the language that is. Speech withheld. Signification degree zero. A prophecy of the creaturely.

As such, the hero's silent revolt, her revolt of silence, points to an interruption on a different plane: that of history. Little wonder, then, that no specification of the object of prophetic speech can be found in Benjamin's text, as the intention of that speech would only be legible in that historical moment which fulfils it, the one that would recognize itself in it and thus become a present. The prophecy Benjamin finds in tragedy - the expressionless silence of the body beyond all aesthetics - is not oriented towards a goal, but towards disruption of time in a present to come, a present whose shape remains undetermined until then. The ban on images has become materialistic. For what the consummate negativity of the expressionless 'speaks of' is none other than this present, the interruption of the reign of the 'until now.' It does so with a word that is no longer one, in, and as silence: "among all words it is the most perverse, or the most poetic: it is the token of its own death [...] a word which is not a word" (Bataille 145). 


\section{Works Cited}

Adorno, Theodor W. “Charakteristik Walter Benjamins.” Gesammelte Schriften. Ed. Rolf Tiedemann. Vol. X/I. Frankfurt a.M.: Suhrkamp, 2003. 203-15.

Agamben, Giorgio. “On Potentiality." Potentialities: Collected Essays in Philosophy. Ed. and trans. Daniel Heller-Roazen. Stanford, CA: Stanford UP, 1999. 177-84.

Agamben, Giorgio. State of Exception. Trans. Kevin Attell. Chicago and London: The U of Chicago P, 2005.

Alt, Peter-André. “Subjektivierung, Ritual, implizite Theatralität. Hölderlins ‘Empedokles’ - Projekt und die Diskussion des antiken Opferbegriffs im 18. Jahhundert." Hölderlin-Jahrbuch 37 (2011): 30-67.

Asman, Carrie L. "Theater and Agon/Agon and Theater: Walter Benjamin and Florens Christian Rang." Modern Langauge Notes 107 (1992): 606-24.

Baillot, Anne. Genèse et réception de la pensée esthétique de K. W. F. Solger entre 1800 et 1830. Doctoral thesis. Université Paris VIII Vincennes-Saint Denis, 2002.

Bataille, Georges. Inner Experience. Trans. Leslie A. Boldt. Albany, NY: State U of New York P, 1988.

Benjamin, Walter. “An Florens Christian Rang. Berlin, 14. 2. 1924.” Gesammelte Briefe. Vol. II. Eds. Christoph Gödde and Henri Lonitz. Frankfurt a.M.: Suhrkamp, 1997. 423-5.

Benjamin, Walter. “An Gershom Scholem. Frankfurt a.M. 19. 2. 1925." Gesammelte Briefe. Vol. III. Eds. Christoph Gödde and Henri Lonitz. Frankfurt a.M.: Suhrkamp, 1997. 13-21.

Benjamin, Walter. “An Hugo von Hofmannsthal. Berlin, 28. 12. 1925.” Gesammelte Briefe. Vol. III. Eds. Christoph Gödde and Henri Lonitz. Frankfurt a.M.: Suhrkamp, 1997. 104-7.

Benjamin, Walter. The Arcades Project. Trans. Howard Eiland and Kevin McLaughlin. Cambridge, MA, and London: The Belknap P of Harvard UP, 1999.

Benjamin, Walter. "Der Begriff der Kunstkritik in der deutschen Romantik." Gesammelte Schriften. Vol. I. 9-123.

Benjamin, Walter. "Fate and Character.” Trans. Edmund Jephcott. Selected Writings. Vol. I. Ed. Michael W. Jennings. Cambridge, MA: The Belknap P of Harvard UP, 1996. 201-7.

Benjamin, Walter. Gesammelte Schriften. Vol. I. Eds. Rolf Tiedemann and Hermann Schweppenhäuser. Frankfurt a.M.: Suhrkamp, 1991.

Benjamin, Walter. Gesammelte Schriften. Vol. II. Eds. Rolf Tiedemann and Hermann Schweppenhäuser. Frankfurt a.M.: Suhrkamp, 1991.

Benjamin, Walter. “Goethe's Elective Affinities.” Trans. Stanley Corngold. Selected Writings. Vol. I. Ed. Michael W. Jennings. Cambridge, MA: The Belknap P of Harvard UP, 1996. 297-360.

Benjamin, Walter. “Goethes Wahlverwandtschaften.” Gesammelte Schriften. Vol. I. 123-201.

Benjamin, Walter. "Karl Kraus.” Gesammelte Schriften. Vol. II. 334-67.

Benjamin, Walter. "Das Kunstwerk im Zeitalter seiner technischen Reproduzierbarkeit.” Gesammelte Schriften. Vol. I. 431-69.

Benjamin, Walter. "Literaturgeschichte und Literaturwissenschaft." Gesammelte Schriften. Vol. III. Eds. Rolf Tiedemann and Hermann Schweppenhäuser. Frankfurt a.M.: Suhrkamp, 1991. 283-90.

Benjamin, Walter. “Das Passagen-Werk”. Gesammelte Schriften. Vol. V. Eds. Rolf Tiedemann and Hermann Schweppenhäuser. Frankfurt a. M.: Suhrkamp, 1991.

Benjamin, Walter. "Schicksal und Charakter." Gesammelte Schriften. Vol. II. 173-9. 
Benjamin, Walter. “To Gershom Scholem. Frankfurt am Main, February 19, 1925." The Correspondence of Walter Benjamin 1910-1940. Eds. Gershom Scholem and Theodor W. Adorno. Trans. Manfred R. Jacobson and Evelyn M. Jacobson. Chicago: Chicago UP, 1994. 260-3.

Benjamin, Walter. “To Hugo von Hofmannsthal. Berlin, December 28, 1925." The Correspondence of Walter Benjamin 1910-1940. Eds. Gershom Scholem and Theodor W. Adorno. Trans. Manfred R. Jacobson and Evelyn M. Jacobson. Chicago: Chicago UP, 1994. 286-7.

Benjamin, Walter. “Ursprung des deutschen Trauerspiels." Gesammelte Schriften. Vol. I. 203430.

Benjamin, Walter. "The Work of Art in the Age of Mechanical Reproduction." Trans. Edmund Jephcott and Harry Zohn. Selected Writings. Vol. III. Ed. Michael W. Jennings. Cambridge, MA: The Belknap P of Harvard UP, 1996. 101-33.

Billings, Joshua. Genealogy of the Tragic: Greek Tragedy and German Philosophy. Princeton, NJ: Princeton UP, 2014.

Billings, Joshua. "Margins of Genre: Walter Benjamin and the Idea of Tragedy." Tragedy and the Idea of Modernity. Eds. Joshua Billings and Miriam Leonard. Oxford: Oxford UP, 2015. 26684.

Bohrer, Karl Heinz. Der Abschied: Theorie der Trauer: Baudelaire, Goethe, Nietzsche, Benjamin. Frankfurt a.M.: Suhrkamp, 1996.

Bohrer, Karl Heinz. Das Tragische: Erscheinung, Pathos, Klage. Munich: Hanser, 2009.

Dastur, Françoise. Hölderlin: Le retournement natal: Tragédie et Modernité \& Nature et Poésie. La Versanne: encre marine, 1997.

Decher, Friedhelm. Die Ästhetik K. W. F. Solgers. Heidelberg: Winter, 1994.

Deleuze, Gilles. “To Have Done with Judgement." Essays Critical and Clinical. Trans. Daniel W. Smith and Michael A. Greco. London and New York: Verso, 1998. 126-35.

Elkins, James, and Harper Montgomery, eds. Beyond the Aesthetic and the Anti-Aesthetic. University Park, PA: The Pennsylvania State UP, 2013.

Féher, Ferenc. "Lukács and Benjamin: Parallels and Contrasts.” New German Critique 35 (1985): 125-38.

Fenves, Peter. "Tragedy and Prophecy in Benjamin's Origin of the German Mourning Play." Benjamin's Ghosts: Interventions in Contemporary Literary and Cultural Theory. Ed. Gerhard Richter. Stanford, CA: Stanford UP, 2002. 237-59.

Ferris, David. Silent Urns: Romanticism, Hellenism, Modernism. Stanford, CA: Stanford UP, 2000.

Foster, Hal, ed. The Anti-Aesthetic: Essays on Postmodern Culture. Seattle: Bay Press, 1983.

Gordon, Peter E. Rosenzweig and Heidegger: Between Judaism and German Philosophy. Berkeley, CA: U of California P, 2003.

Hamacher, Werner. “'NOW': Walter Benjamin on Historical Time." The Moment: Time and Rupture in Modern Thought. Ed. Heidrun Friese. Liverpool: Liverpool UP, 2001. 161-96.

Hamacher, Werner. “Parusie, Mauern: Mitteilbarkeit und Zeitlichkeit, später Hölderlin.” Hölderlin-Jahrbuch 34 (2004/2005): 93-142.

Hanssen, Beatrice. Walter Benjamin's Other History: Of Stones, Animals, Human Beings, and Angels. Berkeley, CA: U of California P, 1998.

Hegel, G. W. F. Aesthetics. Lectures on Fine Art. Vol. II. Trans. T. M. Knox. Oxford: Clarendon Press, 1975.

Hegel, G. W. F. The Scientific Ways of Treating Natural Law, Its Place in Moral Philosophy, and Its Relation to the Positive Sciences of Law. Trans. T. M. Knox. Philadelphia: U of Pennsylvania P, 1975. 
Hegel, G. W. F. "Solgers nachgelassene Schriften und Briefwechsel.” Werke. Vol. XI. Eds.

Eva Moldenhauer and Klaus Markus Michels. Frankfurt a.M.: Suhrkamp, 1986. 205-74.

Hegel, G. W. F. “Über die wissenschaftlichen Behandlungsarten des Naturrechts, seine Stelle in der praktischen Philosophie und sein Verhältnis zu den positiven Rechtswissenschaften." Werke. Vol. II. Eds. Eva Moldenhauer and Klaus Markus Michels. Frankfurt a.M.: Suhrkamp, 1986. 434-503.

Hegel, G. W. F. Vorlesungen über die Ästhetik III. Werke. Vol. XV. Eds. Eva Moldenhauer and Klaus Markus Michels. Frankfurt a. M.: Suhrkamp, 1986.

Henckmann, Wolfhart. "Solger und die Berliner Kunstszene.” Kunsterfahrung und Kulturpolitik im Berlin Hegels. Eds. Otto Pöggeler and Anne Gethmann-Siefert. Bonn: Bouvier, 1983. 199-228.

Henckmann, Wolfhart. “Solgers Schellingstudium in Jena 1801/02.” Hegel-Studien 13 (1978): 53-74.

Henckmann, Wolfhart. "Symbolische und allegorische Kunst bei Solger." Früher Idealismus und Frühromantik: Der Streit um die Grundlagen der Ästhetik (1795-1805). Eds. Walter Jaeschke and Helmut Holzhey. Hamburg: Meiner, 1990. 214-40.

Hölderlin, Friedrich. “Anmerkungen zur Antigonae.” Sämtliche Werke (Große Stuttgarter Ausgabe). Vol. V. Ed. Friedrich Beißner. Stuttgart: W. G. Kohlhammer, 1957. 265-72.

Hölderlin, Friedrich. "Celebration of Peace.” Poems and Fragments. Trans. and ed. Michael Hamburger. London: Anvil Press, ${ }^{3} 1994.460-1$.

Hölderlin, Friedrich. “Friedensfeier.” Sämtliche Werke (Große Stuttgarter Ausgabe). Vol. III. Ed. Friedrich Beißner. Stuttgart: W. G. Kohlhammer, 1957. 532-8.

Hölderlin, Friedrich. "The Ground for Empedocles." Essays and Letters On Theory. Trans. and ed. Thomas Pfau. Albany, NY: State U of New York P, 1988. 50-61.

Hölderlin, Friedrich. “Grund zum Empedokles.” Sämtliche Werke (Große Stuttgarter Ausgabe). Vol. IV. Ed. Friedrich Beißner. Stuttgart: W. G. Kohlhammer, 1957. 149-62.

Hölderlin, Friedrich. Hyperion. Sämtliche Werke (Große Stuttgarter Ausgabe). Vol. III. Ed. Friedrich Beißner. Stuttgart: W. G. Kohlhammer, 1957.

Hölderlin, Friedrich. Hyperion. Trans. Willard R. Trask and David Schwarz. Hyperion and Selected Poems. Ed. Eric L. Santner. New York: Continuum, 1990. 1-133.

Hölderlin, Friedrich. “Hyperion's Song of Fate." Poems and Fragments. Trans. and ed. Michael Hamburger. London: Anvil Press, ${ }^{3} 1994.65$.

Hölderlin, Friedrich. "Remarks on 'Antigone'." Essays and Letters On Theory. Trans. and ed. Thomas Pfau. Albany, NY: State U of New York P, 1988. 100-16.

Hölderlin, Friedrich. Sämtliche Werke und Briefe. Vols. 2 and 3. Ed. Franz Zinkernagel. Leipzig: Insel, 1914-1915.

Helfer, Martha B. “Benjamin and the 'Birth of Tragedy’: The Trauerspiel Essays, 1916-1926.” Kodikas/Codes. Ars Semeiotica 11.1-2 (1988): 179-93.

Honold, Alexander. “Benjamins Konzept des Tragischen.” Benjamins Wahlverwandschaften: Zur Kritik einer programmatischen Interpretation. Eds. Helmut Hühn, Jan Urbich, and Uwe Steiner. Berlin: Suhrkamp, 2015. 287-301.

Hühn, Lore, and Philipp Schwab, eds. Die Philosophie des Tragischen. Schopenhauer - Schelling - Nietzsche. Berlin: De Gruyter, 2011.

Jamme, Christoph. “Ein ungelehrtes Buch”: Die philosophische Gemeinschaft zwischen Hölderlin und Hegel in Frankfurt 1797-1800. Bonn: Bouvier, 1983.

Jäger, Lorenz. Messianische Kritik: Studien zu Leben und Werk von Florens Christian Rang. Cologne: Böhlau, 1998. 
Jennings, Michael W. Dialectical Images: Walter Benjamin's Theory of Literary Criticism. Ithaca, NY: Cornell UP, 1987.

Krell, David Farrell. The Tragic Absolute: German Idealism and the Languishing of God. Bloomington and Indianapolis, IN: Indiana UP, 2005.

Lacoue-Labarthe, Philippe. "La césure du spéculatif." L'imitation des Modernes: Typographies II. Paris: Galilée, 1986. 39-69.

Lacoue-Labarthe, Philippe. L'imitation des Modernes: Typographies II. Paris: Galilée, 1986.

Lacoue-Labarthe, Philippe. Métaphrasis, suivi de Le théâtre de Hölderlin. Paris: Presses Universitaires de France, 1998.

Lemke, Anja. “'Nichts als Zeit' - Zum Verhältnis von Sprache, Gott und Geschichte in Hölderlins Tragödienkonzeption." "Es bleibet aber eine Spur / Doch eines Wortes." Zur späten Hymnik und Tragödientheorie Friedrich Hölderlins. Eds. Christoph Jamme and Anja Lemke. Munich: Fink, 2004. 401-18.

Mack, Dietrich. Ansichten zum Tragischen und zur Tragödie: Ein Kompendium der deutschen Theorie im 20. Jahrhundert. Munich: Fink, 1970.

Mali, Joseph. "The Reconciliation of Myth: Benjamin's Homage to Bachofen.” Journal of the History of Ideas 60.1 (1999): 165-87.

McFarland, James. “The Death of Tragedy: Walter Benjamin's Interruption of Nietzsche's Theory of Tragedy." Tragedy and the Tragic in German Literature, Art, and Thought. Eds. Stephen D. Dowden and Thomas P. Quinn. Rochester, NY: Camden House, 2014. 171-94.

Menninghaus, Winfried. “Das Ausdruckslose: Walter Benjamins Kritik des Schönen durch das Erhabene.” Walter Benjamin 1892-1940. Ed. Uwe Steiner. Bern: Peter Lang, 1992. 33-76.

Menninghaus, Winfried. Schwellenkunde: Walter Benjamins Passage des Mythos. Frankfurt a.M.: Suhrkamp, 1986.

Mosès, Stéphane. Système et Révélation: La Philosophie de Franz Rosenzweig. Paris: Éditions du Seuil, 1982.

Mosès, Stéphane. “Walter Benjamin und Franz Rosenzweig." Deutsche Vierteljahresschrift für Literaturwissenschaft und Geistesgeschichte 56.4 (1982): 622-40.

Most, Glenn W. “Schlegel, Schlegel und die Geburt eines Tragödienparadigmas.” Poetica 25.1-2 (1993): 155-75.

Newman, Jane O. Benjamin's Library: Modernity, Nation, and the Baroque. Ithaca, NY: Cornell UP, 2011.

Nietzsche, Friedrich. The Birth of Tragedy and other Writings. Trans. Ronald Speirs. Cambridge: Cambridge UP, 1999.

Nietzsche, Friedrich. Die Geburt der Tragödie aus dem Geiste der Musik. Kritische Studienausgabe. Vol. I. Eds. Giorgio Colli and Mazzino Montinari. Munich: dtv, 1999.

Rochlitz, Rainer. Le désenchantement de l'art: La philosophie de Walter Benjamin. Paris: Gallimard, 1992.

Rosenzweig, Franz. The Star of Redemption. Trans. Barbara E. Galli. Wisconsin: The U of Wiscon$\sin \mathrm{P}, 2005$.

Rosenzweig, Franz. Der Stern der Erlösung. 1921. Frankfurt a. M.: Suhrkamp, 1988.

Sagnol, Mac. Tragique et tristesse: Walter Benjamin, archéologue de la modernité. Paris: Cerf, 2003.

Santner, Eric L. On Creaturely Life: Rilke / Benjamin / Sebald. Chicago: Chicago UP, 2006.

Santner, Eric L. On the Psychotheology of Everyday Life: Reflections on Freud and Rosenzweig. Chicago: Chicago UP, 2001. 
Schelling, F. W. J. Philosophie der Kunst. Sämtliche Werke. Div. I, vol. V. Ed. Karl Friedrich August Schelling. Stuttgart: J. G. Cotta, 1859.

Schelling, F. W. J. The Philosophy of Art. Trans. Douglas W. Stott. Minneapolis: Minnesota UP, 1989.

Schlegel, A. W. Vorlesungen über schöne Literatur (Berlin lectures 1801-1804). Kritische Ausgabe der Vorlesungen. Vol. I. Ed. Ernst Behler. Paderborn: Schöningh, 1989.

Schmidt, Denis J. On Germans and other Greeks: Tragedy and Ethical Life. Indiana: Indiana UP, 2001.

Scholem, Gershom. Walter Benjamin: Geschichte einer Freundschaft. Frankfurt a.M.: Suhrkamp, 1975.

Schürmann, Reiner. "Legislation/Transgression: Strategies and Counter-Strategies in the Transcendental Justification of Norms." Tomorrow the Manifold: Essays on Foucault, Anarchy and the Singularization to Come. Eds. Malte Fabian Rauch and Nicolas Schneider. Zurich and Berlin: Diaphanes, 2018. 76-103.

Silk, Michael Stephen, and Joseph Peter Stern. Nietzsche on Tragedy. Cambridge, MA: Cambridge UP, 1981.

Solger, K. W. F. "Beurtheilung der Vorlesungen über dramatische Kunst und Literatur." Nachgelassene Schriften und Briefwechsel. Vol. II. Eds. Ludwig Tieck and Friedrich von Raumer. Leipzig: F. A. Brockhaus, 1826; repr. Heidelberg: Lambert Schneider, 1973. 396-414.

Solger, K. W. F. Des Sophokles Tragödien. 2 vols. Berlin: Realschulbuchhandlung, 1808.

Solger, K. W. F. “Über Sophokles und die alte Tragödie.” Nachgelassene Schriften und Briefwechsel. Vol. II. Eds. Ludwig Tieck and Friedrich von Raumer. Leipzig: F. A. Brockhaus, 1826; repr. Heidelberg: Lambert Schneider, 1973. 445-92.

Solger, K. W. F. “Über die Wahlverwandtschaften.” Nachgelassene Schriften und Briefwechsel. Vol. I. Eds. Ludwig Tieck and Friedrich von Raumer. Leipzig: F. A. Brockhaus, 1826; repr. Heidelberg: Lambert Schneider, 1973. 175-85.

Szondi, Peter. Von der normativen zur spekulativen Gattungspoetik. Ed. Wolfgang Fietkau. Poetik und Geschichtsphilosophie. Vol. II. Eds. Jean Bollack et al. Frankfurt a.M.: Suhrkamp, 1974.

Szondi, Peter. Versuch über das Tragische. Schriften. Vol. I. Eds. Jean Bollack et al. Frankfurt a. M.: Suhrkamp, 2011.

Taminiaux, Jacques. Le théâtre des philosophes: La tragédie, l'être, l'action. Grenoble: Jérôme Milon, 1995.

Thaler, Jürgen. Dramatische Seelen: Tragödientheorien im frühen zwanzigsten Jahrhundert. Bielefeld: Aisthesis, 2003.

Walzel, Oskar. "Tragik bei Solger." Helicon. Revue Internationale des Problems Généraux de la Littérature 3 (1940): 27-49.

Weber, Samuel. "Storming the Work: Allegory and Theatricality in Benjamin's Origin of the German Mourning Play." Theatricality as Medium. New York: Fordham UP, 2004. 160-80.

Wellbery, David E. "Form und Funktion der Tragödie nach Nietzsche.” Tragödie - Trauerspiel Spektakel. Eds. Bettina Menke and Christoph Menke. Berlin: Theater der Zeit, 2007. 199212.

von Wilamowitz-Möllendorff, Ulrich. Einleitung in die griechische Tragödie (Unchanged facsimile reprint of the first edition of Euripides Herakles. Vol. I. Chs. I-IV). Berlin: Weidmannsche Buchhandlung, 1907.

von Wilamowitz-Möllendorff, Ulrich. Zukunftsphilologie! Eine Erwidrung auf Friedrich Nietzsches “Geburt der Tragödie.” Berlin: Borntraeger, 1872. 